\title{
Fragile Scream
}

Ahmed Z. Obeidat, MD, PhD

Neurology ${ }^{\circledR}$ 2018;90:427. doi:10.1212/WNL.0000000000005015

My chest is fragile

My airways are tight

My throat is sore

My eyes are dry

My skin is wrinkled

My skin is bruised

My soul is captive, helpless, and shy

My brain is sodden with memories and dreams

Not only what you view

Angry bursts and silence too

I am here

I hear you

I see your nebulous faces

Don't pinch me

Don't squeeze me

Let me die

Don't tap on my ankles, knees, and jaw

My spine is working; disconnected from my brain, though

I've heard how atrophic my brain was

But please don't forget the decades of collective wisdom and pride

I dreamt of my boyhood home

Grandma's delicious chicken soup and a freshly baked Cinnamon-Raisin loaf

You may say, it could be your last

Yes, but for me, it is a wonderful experience from my past

You would rather feed me through a tube

Yellow, runny, and tasteless gruel

Don't pinch me

Don't squeeze me

Let me die

I am too drained to move

Too tired to talk

Blink my eyes

Move my mouth

Or even lick lips so dry

You see me on your rounds

But I am lying there; can't move

Waiting for my soul to escape through the cracks

And for my body to rest in the dark

My family may tell you: Full code; bring him back

But I say: Don't squeeze

And in peace, let me die, please.

\section{Correspondence}

Dr. Obeidat

ahmed.obeidat@uc.edu

MORE ONLINE

ค Audio

Listen to Dr. Obeidat read this poem.

NPub.org/xj24pi 


\title{
Neurology
}

\author{
Fragile Scream \\ Ahmed Z. Obeidat \\ Neurology 2018;90;427 \\ DOI 10.1212/WNL.0000000000005015
}

This information is current as of February 26, 2018

\section{Updated Information \& Services}

\section{Subspecialty Collections}

Permissions \& Licensing

\section{Reprints}

including high resolution figures, can be found at: http://n.neurology.org/content/90/9/427.full

This article, along with others on similar topics, appears in the following collection(s):

\section{All Ethics in Neurology/Legal issues}

http://n.neurology.org/cgi/collection/all_ethics_in_neurology_legal_iss ues

\section{All Pain}

http://n.neurology.org/cgi/collection/all_pain

\section{Professional conduct and ethics}

http://n.neurology.org/cgi/collection/professional_conduct_and_ethics

Information about reproducing this article in parts (figures,tables) or in its entirety can be found online at:

http://www.neurology.org/about/about_the_journal\#permissions

Information about ordering reprints can be found online:

http://n.neurology.org/subscribers/advertise

Neurology ${ }^{\circledR}$ is the official journal of the American Academy of Neurology. Published continuously since 1951, it is now a weekly with 48 issues per year. Copyright () 2018 American Academy of Neurology. All rights reserved. Print ISSN: 0028-3878. Online ISSN: 1526-632X.

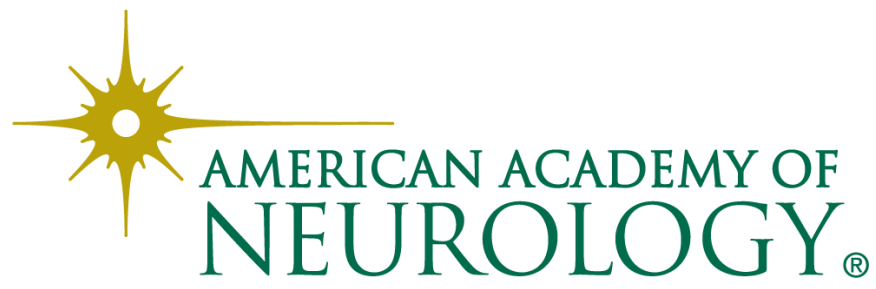

